\title{
The Settled Sanction: Post-Settlement Appeal and Vacatur of Attorney Sanctions Payable to an Opponent
}

\author{
David Scharf $\dagger$
}

Over the past decade, federal courts have come to rely primarily on sanctions to control the conduct of attorneys. ${ }^{1}$ Often, courts hold lawyers and their clients jointly and severally liable for conduct such as discovery abuse, unwarranted factual contentions, vexatious multiplication of the proceedings, or civil contempt. ${ }^{2}$ When courts impose monetary sanctions, they usually make the sanctions payable to the opposing party. ${ }^{3}$ If sanctions are payable to an opponent, rather than the court, a client can settle the case and all related sanctions.

Although the client may appraise the sanction at approximately its face value, the lawyer, a repeat player in the judicial system, usually attaches far greater significance to the sanction. ${ }^{4}$ Even when a client fails to seek contribution for payment of a

$\dagger$ B.S. 1990, Indiana University; J.D. 1994, The University of Chicago.

1 "With only a small risk of overstatement, one could say that sanctions in civil litigation exploded during the 1980s, with the 1983 amendment to Federal Rule of Civil Procedure 11 acting as the principal catalyst." Jeffrey W. Stempel, Sanctions, Symmetry, and Safe Harbors: Limiting Misapplication of Rule 11 by Harmonizing It With Pre-Verdict Dismissal Devices, 60 Fordham L Rev 257, 257 (1991). The recent amendment to Rule 11, effective December 1, 1993, provides for voluntary withdrawal of challenged papers and may slow or reverse this trend. See Robert E. Bartkus, Rule 11's New Teeth Have a Broader Bite, NJ L J 11 (Dec 20, 1993).

2 The courts derive their power in these circumstances from, respectively, FRCP 37, FRCP 11, 28 USC $\S 1927$ (1988), and 18 USC $\S 401$ (1988). The courts also have inherent power to control the conduct of parties before them. See Chambers $v$ NASCO, Inc., 501 US $32,43-44$ (1991).

${ }^{3}$ Melissa L. Nelkin, Sanctions Under Amended Federal Rule 11-Some "Chilling" Problems in the Struggle Between Compensation and Punishment, 74 Georgetown L J 1313,1333 (1986) (96\% of cases in study involved payment to an opponent rather than to the court). The 1993 amendment to Rule 11, however, deemphasizes the payment of sanctions to opponents. See the limits on monetary sanctions in Rule 11(c)(2)(A). The advisory committee notes would limit the payment of sanctions to an opponent to "unusual circumstance[s]." At the same time, Rule 11(d) moves discovery sanctions to the more compensation-friendly Rule 37.

4 Stephen M. Bundy and Einer R. Elhauge, Do Lawyers Improve the Adversary System? A General Theory of Litigation Advice and Its Regulation, $79 \mathrm{Cal} \mathrm{L}$ Rev 313,354 (1991). 
fine for which the lawyer is jointly liable, the lawyer has enduring interests. ${ }^{5}$ The judgment threatens the lawyer's reputation, ${ }^{6}$ malpractice insurance rates, ${ }^{7}$ and perhaps bar membership. ${ }^{8}$ Somewhat unrealistically, the lawyer is expected to ignore these interests and assist the client's best settlement. ${ }^{9}$

Once the client settles the full case, the lawyer faces a "settled sanction": ${ }^{10}$ the judgment imposing the sanction remains on the books, but the lawyer has no direct monetary obligation to the opposing party. To avoid the adverse effects of the judgment, the lawyer would like to appeal it or have it deprived of its force through vacatur.

Both options present problems. The sanctioned lawyer would, of course, prefer vacatur to an appeal tested under an abuse-ofdiscretion standard. ${ }^{11}$ If courts are too willing to expunge the adverse judgment from the lawyer's record, however, they risk undermining the sanctions regime, and they encourage the lawyer to promote a settlement for reasons unrelated to the client's interests. Appeals are not without problems either, as a court may find that the lawyer's interest in his reputation does not satisfy Article III's case or controversy requirement, or, if that interest does satisfy the constitutional demands, that it is not significant enough to justify expending judicial resources.

5 See Perkins v General Motors Corp., 965 F2d 597, 599 (8th Cir 1992), cert denied, 113 S Ct 654 (1992) (allowing an appeal although the trial court issued sanctions without a specific monetary fine, because an attorney should not have to forfeit a personal right to appeal sanctions levied against him).

- Business reputation is particularly important to attorneys. Since clients often lack the ability to assess lawyers' skills, reputation serves as a proxy for quality and integrity. Geoffrey P. Miller, Some Agency Problems in Settlement, 16 J Legal Stud 189, 210 (1987).

7 Thomas E. Willging, The Rule 11 Sanctioning Process, 1988 WL 252121 (FJC), *330. (malpractice insurance carriers require that the imposition of sanctions be reported to them).

${ }^{8}$ McGoldrick Oil Co. v Campbell, 793 F2d 649, 654 (5th Cir 1986) (informing bar authorities of lawyer's activities); Steinle $v$ Warren, 765 F2d 95, 102 (7th Cir 1985) (same).

9 See Richardson-Merrell Inc. $v$ Koller, 472 US 424, 435 (1985), citing ABA Model Rules of Professional Conduct 1.7(b), 2.1 (1985). See also Evans $v$ Jeff D., 475 US 717, 728 n 14 (1986), citing Model Rules: "Generally speaking, a lawyer is under an ethical obligation to exercise independent professional judgment on behalf of his client; he must not allow his own interests, financial or otherwise, to influence his professional advice." See also Note, Rule 11 and Its Effect on Attorney/Client Relations, $65 \mathrm{~S}$ Cal L Rev 875, 896-97 (1992).

${ }_{10}$ This Comment does not address a lawyer's right to an interlocutory appeal of a sanction. Accordingly, the Comment ignores issues such as a lawyer's nonparty status. For a description of the circuits' disagreement over interlocutory appeal, see Sanders Associates, Inc. v Summagraphics Corp., 2 F3d 394, 395-97 (Fed Cir 1993).

1 See Cooter \& Gell v Hartmarx Corp., 496 US 384, 405 (1990) (establishing abuse of discretion as the standard of review for attorney sanctions). 
The circuit courts reviewing appeals of "settled sanctions" have taken divergent positions. One agreed to hear the appeal, and reviewed it under the deferential abuse-of-discretion standard. ${ }^{12}$ Other courts refused to hear such appeals, dismissing them for mootness. ${ }^{13}$ Where courts dismiss appeals of settled sanctions, lawyers generally have no cause for complaint, as the appellate courts typically vacate the lower court's sanction. However, one court refused to vacate the unappealable sanction, leaving the lawyer frustrated. ${ }^{14}$

This Comment reviews the varying approaches, and argues that a policy of allowing appeal of settled sanction cases is faithful to the Constitution and best serves the interests of the judicial system. Section I takes a look at mootness and vacatur, the doctrines most relevant to settled sanction cases. The discussion then turns to appellate decisions of settled sanction cases. These decisions typically rule on the question of mootness, or on the propriety of vacatur, without much explanation. To fill this void, Section II considers how the doctrines of mootness and vacatur apply to appeals of settled sanctions. This analysis leads to the conclusion that courts should allow an appeal. The Constitution does not bar an appeal, and the settled sanction does not meet the normal standard for prudential mootness. If a court nonetheless denies an appeal, it should vacate the judgment of the lower court. Section III explores the implications of, and identifies the policies served by, a rule granting appeals.

\section{MOOTNESS, VAcatUR, AND SETTLED SANCTIONS: UNSETTled DOCTRINE, UNCERTAIN INTERESTS}

The circuit courts have divided over how to apply the mootness and vacatur doctrines to settled sanction cases. The existence of such disagreements is hardly surprising, given the confusion and disagreement that surround the two doctrines. This Section first attempts to clarify some fundamental elements of the two doctrines, and then reviews the courts' cursory application of the doctrines to settled sanction cases.

12 Perkins, 965 F2d at 599-600.

13 Clark Equipment Co. v Lift Parts Mfg. Co., 972 F2d 817 (7th Cir 1992); Riverhead Savings Bank v Nat'l Mortgage Equity Corp., 893 F2d 1109 (9th Cir 1990); Kleiner v First Natl Bank of Atlanta, 751 F2d 1193 (11th Cir 1985).

14 Riverhead, 893 F2d at 1113. 


\section{A. Mootness: Judicial Power and Individual Interests}

The mootness doctrine requires a party to maintain a personal stake in the outcome of the proceedings throughout the case. ${ }^{15}$ "Simply stated, a case is moot when the issues presented are no longer 'live' or the parties lack a legally cognizable interest in the outcome."16 Once a case becomes moot, the federal courts lose jurisdiction to hear it. ${ }^{17}$

Mootness has developed as a mix of constitutional requirements and policy considerations, without a clear division of the two bases. Although the entire area remains poorly defined, ${ }^{18}$ it can be divided into constitutional mootness, which prohibits a court from hearing a dispute that does not qualify as a case or controversy, and prudential mootness, which allows an appellate court to refuse an appeal that falls within the court's constitutional reach.

\section{Constitutional mootness.}

The precise scope of constitutional mootness remains a matter of debate. Frequently, the Supreme Court avoids significant evaluation of the doctrine by citing the doctrine's "uncertain and shifting contours"19 or by declining to explain its application to a particular case. ${ }^{20}$ Although the Court has employed the mootness doctrine for almost a century, ${ }^{21}$ it first explicitly linked mootness to the Constitution in dicta found in a footnote to a 1964 case:

Our lack of jurisdiction to review moot cases derives from the requirement of Article III of the Constitution under

15 Lewis $v$ Continental Bank Corp., 494 US 472, 477 (1990).

${ }_{16}$ Powell $v$ McCormack, 395 US 486, 496 (1969).

17 North Carolina $v$ Rice, 404 US 244, 246 (1971).

${ }_{18}$ "Trying to square a constitutional aversion to moot cases with the reality that at least several members of the Supreme Court have likely meant to reach the merits of the substantive dispute, or else they would not have accepted the case for review, has caused eminent jurists-with some frequency-to say very silly and indefensible things." Gene $R$. Nichol, Jr., Moot Cases, Chief Justice Rehnquist, and the Supreme Court, 22 Conn L Rev 703, 708 (1990). (1980).

${ }_{19}$ See, for example, United States Parole Comm'n v Geraghty, 445 US 388, 401

${ }^{20}$ Charles A. Wright, Arthur R. Miller, and Edward H. Cooper, 13A Federal Practice and Procedure \$ 3533.1 at 225-26 (West, 2d ed 1984).

${ }_{21}$ According to Chief Justice Rehnquist's concurring opinion in Honig $v$ Doe, 484 US 305, 329-30 (1988), the Supreme Court first discussed mootness in Mills $v$ Green, 159 US 651 (1895). 
which the exercise of judicial power depends upon the existence of a case or controversy. ${ }^{22}$

Generally, this doctrine limits the courts to their appropriate roles in the constitutional framework and their areas of institutional competence. ${ }^{23}$ The courts must resolve specific disputes, not declare law in the abstract. Thus, they require that a litigant maintain a "personal stake"24 or "legally cognizable interest" throughout the case, so that the courts will resolve only "real and substantial controversies admitting of specific relief through a decree of a conclusive character, as distinguished from an opinion advising what the law would be upon a hypothetical set of facts." 26

This stake requirement does not regulate the size of the interest a party must have, for "[a]s long as the parties have a concrete interest in the outcome of the litigation, the case is not moot notwithstanding the size of the dispute."27 Instead, the stake requirement ensures that the litigant has a personal interest that should be resolved by the judiciary rather than the legislative or executive branches. ${ }^{28}$

\section{Prudential mootness.}

Even if an appeal clears the hurdle of constitutional mootness, a court may declare it moot for prudential reasons. ${ }^{29}$

${ }^{22}$ Liner $v$ Jafco, Inc., 375 US 301, 306 n 3 (1964). See also Sidney A. Diamond, Federal Jurisdiction to Decide Moot Cases, 94 U Pa L Rev 125 (1946).

${ }^{23}$ See Geraghty, 445 US at 397 (mootness doctrine "assur[es] that federal courts are presented with disputes they are capable of resolving").

24 Id at 396.

25 Powell, 395 US at 496.

${ }_{28}$ Lewis $v$ Continental Bank Corp., 494 US 472, 477 (1990), quoting North Carolina $v$ Rice, 404 US 244, 246 (1971), in turn quoting Aetna Life Insurance Co. v Haworth, 300 US 227, 241 (1937).

27 Firefighters Local Union No. $1784 v$ Stotts, 467 US 561, 571 (1984); see also Deposit Guaranty Nat'l Bank $v$ Roper, 445 US 326, 340 (1980) (upholding named plaintiffs' interests in litigating class action in order to spread litigation costs after defendant tendered full individual damages).

${ }_{23}$ Note, however, that the nature of the interest a party must possess in order to avoid mootness remains elusive. See Nichol, 22 Conn L Rev at 711 (cited in note 18) (giving examples of problems with the "capable of repetition yet avoiding review" standard). It often seems the interest required of the party is inversely related to the Court's desire to reach the merits of the case.

29 Wright, Miller, and Cooper, 13A Federal Practice and Procedure $\$ 3533.1$ at 215 (cited in note 20).

Some commentators have argued for making mootness entirely a "prudential doctrine" by freeing it from constitutional restrictions. See Evan T. Lee, Deconstitutionalizing Justiciability: The Example of Mootness, 105 Harv L Rev 603, 609-10 (1992) (advocating a 
Since the Supreme Court can protect its resources by denying certiorari, the Court typically considers only constitutional mootness limits. ${ }^{30}$ The courts of appeals, therefore, have been largely responsible for developing the doctrine of prudential mootness.

Generally, the courts of appeals have restricted their use of prudential mootness to cases where they could not grant "any effectual relief,"31 or where relief was too "attenuated and remote $^{\$ 32}$ to pursue. For example, in Adams $v$ Resolution Trust Corp., the Eighth Circuit refused to require a hearing for the fraud claim of a subordinated debt holder when the Bank Board had already determined that the claims of subordinated debt holders were worthless. ${ }^{33}$ The Seventh Circuit provided perhaps the broadest formulation of the prudential mootness doctrine in Air Line Pilots Association Intl. v UAL Corp., where it declared:

Unless the plaintiff has died and his cause of action has not survived ... it is usually possible to conjure up a set of facts under which the relief sought would make a difference to the parties. But if it would be a very little difference, then to economize on judicial resources as well as to give expression

purely prudential mootness doctrine); Nichol, 22 Conn L Rev 703 (cited in note 18) (suggesting that the Supreme Court "exempt itself from the mootness requirement"); Casenote, Mootness and the Education for All Handicapped Children Act: Timely Decision Saves Judicial and Social Costs-Honig v. Doe, 108 S. Ct. 592 (1988), 57 U Cin L Rev 1101,1118 (1989) (arguing for a "liberal application" of the mootness doctrine). This Section, however, describes prudential mootness as only that part of mootness doctrine that extends beyond constitutional requirements.

Courts have also used the words "prudential mootness" to describe their discretionary power to withhold equitable relief such as a declaratory judgment or injunction. See, for example, Penthouse Intl. Ltd. $v$ Meese, 939 F2d 1011, 1019 (DC Cir 1991); Allende v Shultz, 845 F2d 1111, 1121 (1st Cir 1988) (Breyer concurring). This Comment does not reach these alternative uses.

${ }^{30}$ The Court will not decide a case where it "cannot affect the matter in issue" or grant "any effectual relief whatever." Church of Scientology of California $v$ United States, 113 S Ct 447, 449 (1992) (citation omitted) (refusing to moot case although it could provide only token relief). If the Court had no power to provide relief, it could only grant an advisory opinion, which constitutional mootness forbids. Contrast a complete lack of power, which destroys jurisdiction, with the power to provide only a slim chance of recovery, which circuit courts have used as a basis for denying an appeal on prudential grounds.

${ }^{31}$ Adams v Resolution Trust Corp., 927 F2d 348, 354 (8th Cir 1991).

32 United States $v$ Street, 933 F2d 1010 (6th Cir 1991) (unpublished disposition reported in full at 1991 US App LEXIS 11463). See also First Indiana Federal Savings Bank v FDIC, 964 F2d 503, 507 (5th Cir 1992).

${ }^{33} 927 \mathrm{~F} 2 \mathrm{~d}$ at 354. 
to policies thought inherent in Article III, the case will be declared moot and relief withheld. ${ }^{34}$

In the Seventh Circuit's view, then, a court may weigh the importance of an appeal to the parties against the costs of that appeal to the court. Prudential mootness is not appropriate where relief would make no difference. Prudential mootness could not be reached because the case would be constitutionally nonjusticiable.

The doctrine of mootness thus has two facets, each of which is poorly defined. The constitutional version of mootness restricts the court to its proper role in the constitutional scheme, while the prudential version conserves judicial resources when a court cannot provide significant relief.

\section{B. Vacatur: Accident and Intention}

If a court decides that a lawyer's appeal is moot, the court must next decide whether to vacate the judgment imposing the sanction. Vacatur eliminates the effects of a prior judgment: a vacated judgment has no preclusive effect ${ }^{35}$ and, arguably, no precedential value. ${ }^{36}$ In any event, the settled sanction cases involve actions by district courts; these have no precedential effect beyond their ability to persuade. ${ }^{37}$

The federal courts have broad statutory power to vacate. For example:

The Supreme Court or any other court of appellate jurisdiction may affirm, modify, vacate, set aside or reverse any judgment, decree, or order of a court lawfully brought before it for review, and may remand the cause and direct the entry of such appropriate judgment, decree, or order, or require

34 897 F2d 1394, 1396-97 (7th Cir 1990).

${ }^{35}$ Martinez $v$ Winner, 800 F2d 230, 231 (10th Cir 1986). See generally Jill E. Fisch, Rewriting History: The Propriety of Eradicating Prior Decisional Law Through Settlement and Vacatur, 76 Cornell L Rev 589 (1991).

${ }^{36}$ Los Angeles County v Davis, 440 US 625, 634 n 6 (1979), denies that vacated opinions have precedential value, but some circuit courts disagree. See Oklahoma Radio Ass'n v FDIC, 3 F3d 1436, 1437 (10th Cir 1993); United States $v$ Articles of Drug Consisting of 203 Paper Bags, 818 F2d 569, 572 (7th Cir 1987).

${ }^{37}$ Smith $v$ State Farm Mutual Auto Ins. Co., 964 F2d 636, 638 (7th Cir 1992). When a circuit court vacates a district court's judgment, the circuit court typically leaves the lower court's opinion in place. Of course, if the district court's opinion reaches the reporters, the circuit court has no power to destroy the opinion itself. Gould $v$ Bowyer, 11 F3d 82, 84 (7th Cir 1993). 
such further proceedings to be had as may be just under the circumstances. ${ }^{38}$

Although this statutory grant invests the federal courts with substantial discretionary power, the Supreme Court has limited this power in some classes of cases.

In United States $v$ Munsingwear, Inc., the Court eliminated judicial discretion over vacatur in civil cases that become moot on appeal through no fault of the appellant. ${ }^{39}$ The Court explained the "duty" of an appellate court to reverse or vacate and remand with instructions to dismiss when a decision becomes moot "through happenstance." Munsingwear thus prevents "a judgment, unreviewable because of mootness, from spawning any legal consequences." ${ }^{11}$

The Supreme Court has not provided such clear guidance for handling vacatur in intentionally mooted cases. ${ }^{42}$ Several circuits have declined to follow Munsingwear when an appeal becomes unreviewable through a choice of the party seeking vacatur. In In re Memorial Hospital of Iowa County, Inc., for example, the Seventh Circuit refused to vacate the lower court's judgment after a voluntary settlement. ${ }^{43}$ The court cited the need to preserve its authority and the public investment of resources in a case that could provide useful precedent or nonmutual preclusion. ${ }^{44}$ Most other circuits have followed Memorial Hospital's lead ${ }^{45}$ or adopted their own case-by-case evaluations. ${ }^{46}$

${ }^{38} 28$ USC \& 2106 (1988). FRCP 60(b) and FRAP 42(b) provide similar power. See

Fisch, 76 Cornell L Rev at 596 (cited in note 35 ).

39340 US 36 (1950).

40 Id at 40.

41 Id at 41 .

42 Izumi Seimitsu Kogyo Kabushiki Kaisha v U.S. Philips Corp., 114 S Ct 425 (1993), provided the Court with an opportunity to unite the divided circuits; however, the Court dismissed the writ of certiorari as improvidently granted. Justice Stevens, in a dissenting opinion, stated that he would have reached the merits and held that Munsingwear "does not apply to mootness achieved by purchase." Id at 428,431 . The Court has taken up the issue again for decision. See U.S. Bancorp Mortgage Company v Bonner Mall Partnership, 1994 US LEXIS 2651.

The Court's earlier decisions are inconsistent. Compare Karcher $v$ May, 484 US 72, 83 (1987) (finding Munsingwear inapplicable where mootness was attributable to a party), with City Gas Co. of Fla. v Consolidated Gas Co. of Fla., Inc., 499 US 915, 915 (1991) (citing Munsingwear while summarily remanding a settled case with instructions to vacate as moot), and Lake Coal Co. v Roberts \& Schaefer Co., 474 US 120 (1985).

4362 F2d 1299 (7th Cir 1988).

44 Id at 1302-03.

${ }_{45}$ In re United States, 927 F2d 626, 627 (DC Cir 1991); Clarendon Ltd. v Nu-West Indus., Inc., 936 F2d 127, 129-30 (3d Cir 1991).

${ }^{46}$ See U.S. Philips Corp. v Windmere Corp., 971 F2d 728, 731 (Fed Cir 1992), cert 
In contrast, the Second Circuit in Nestle Co., Inc. $v$ Chester's Market, Inc. extended the Munsingwear rule to appeals in which the parties voluntarily mooted the case. ${ }^{47}$ The court explained that, "[b]ecause the policies favoring finality of judgments are intended to conserve judicial and private resources, the denial of the motion for vacatur is counterproductive because it will lead to more rather than less litigation. ${ }^{.48}$ Further, although some third party might eventually want to use the court's decision in order to prevent one of the parties to the case from relitigating an issue already resolved against it, the court suggested that this potential for nonmutual preclusion cannot outweigh the interests of the parties in controlling their own case. ${ }^{49}$ Several other circuits have also extended the Munsingwear rule to cover settlements. ${ }^{50}$

It is thus uncontested that a court must vacate a judgment when an appeal becomes moot through no fault of the requesting party.$^{51}$ Courts will not always vacate the lower court judgment, however, when the appeal becomes moot through the choice of a litigant.

\section{The Settled Sanction Cases}

The mootness problem in settled sanction cases does not arise from the mere fact that the underlying controversy has settled; courts unquestionably have the power to hear sanction arguments after the underlying case settles. ${ }^{52}$ Instead, the mootness

granted, Izumi Seimitsu Kogyo Kabushiki Kaiga v U.S. Philips Corp., 113 S Ct 1249 (1993), cert dismissed, 114 S Ct 425 (1993); Ringsby Truck Lines, Inc. v Western Conference of Teamsters, 686 F2d 720, 722 (9th Cir 1982) (appellate courts should balance "competing values of finality of judgment and right to relitigation of unreviewed disputes"); Independent Union of Flight Attendants v Pan American World Airways, Inc., 966 F2d 457, 460 (9th Cir 1992); Oklahoma Radio Assoc., 3 F3d 1436 (10th Cir 1993); Westmoreland $v$ Nat'l Transp. Safety Bd., 833 F2d 1461, 1463 (11th Cir 1987).

4756 F2d 280, 281 (2d Cir 1985).

48 Id at 282. For an assertion that the efficiency argument cuts the other way, see generally Fisch, 76 Cornell L Rev at 632-41 (cited note 35). Compare Note, Settlement Pending Appeal: An Argument for Vacatur, 58 Fordham L Rev 233, 235 (1989) (concluding that courts should grant vacatur to promote settlement given the "speculative and de minimis nature of its attendant costs").

19 Nestle, 756 F2d at 283.

so See Ruiz $v$ Estelle, 688 F2d 266, 267 (5th Cir 1982); Hendrickson v HHS, 774 F2d 1355 (8th Cir 1985); Kennedy $v$ Block, 784 F2d 1220, 1225 (4th Cir 1986). But see Clipper $v$ Takoma Park, 898 F2d 18, 19 (4th Cir 1989) (en banc) (refusing to order panel to withdraw opinion after parties settled). US at 40 .

s1 A party must preserve this right through a motion to vacate. Munsingwear, 340

${ }_{32}$ Cooter \& Gell v Hartmarx Corp., 496 US 384, 395 (1990); Willy v Coastal Corp., 112 S Ct 1076, 1080 (1992). 
problem arises where the settlement of the underlying controversy includes payment of a sanction to the opponent. ${ }^{53}$ In order to avoid mootness objections, the lawyer must show that the existence of the judgment of misconduct, completely apart from payment of the sanction, affects his legal interests.

1. Retaining the sanction.

Of the settled sanction cases, Riverhead Savings Bank $v$ National Mortgage Equity Corp..$^{54}$ involved the least serious allegations of misbehavior. In Riverhead, the district court sanctioned the party and its counsel for filing counter- and crossclaims that were "completely frivolous" and for seeking "grossly inflated damages." ${ }^{.55}$ The attorney and client appealed the sanction, but the client subsequently settled the underlying case and all sanctions payable to the opponent. The attorney and client attempted to continue their appeal of the sanction. ${ }^{56}$

In rejecting the joint appeal of the attorney and client on this issue,${ }^{57}$ the Ninth Circuit implicitly found that an interest in reputation could not fulfill constitutional mootness requirements. ${ }^{58}$ The court instead focused on the monetary aspect of the fine, which the parties had already resolved through settlement. Since an appeal could not affect the payment of the fees, the court mooted the appeal. ${ }^{59}$

In addition, the court refused to vacate the sanction, because the client failed to provide for vacatur in the settlement:

During the settlement talks they specifically bargained over whether the sanctions order should be vacated. [The client], presumably for consideration, agreed to settle without vacation of the order. [The client], after freely negotiating and signing a settlement mooting the appeal without vacating the judgment, is in no position to complain that its right of review of an adverse lower court judgment has been lost. ${ }^{60}$

${ }^{53}$ Riverhead Savings Bank v Nat'l Mortgage Equity Corp., 893 F2d 1109, 1112 (9th Cir 1990).

s. 893 F2d 1109 .

${ }_{55}$ Id at 1111.

${ }^{56}$ Id.

${ }^{57}$ Other portions of the joint appeal survived. Id at 1113.

${ }^{58}$ Id at 1112.

59 Id.

60 Id at 1113 (citations omitted). 
Thus, the court put the case outside the Munsingwear rule that provides for vacatur upon unintentional mootness. As the cited language shows, the court focused on the client's actions, and therefore only on the interests that the client had at stake, while ignoring the lawyer's role in settling the case.

\section{Eliminating the sanction.}

Both the Seventh and the Eleventh Circuits have declared settled sanction appeals moot, but proceeded to vacate the judgments imposing the sanctions. In Clark Equipment Co. $v$ Lift Parts Mfg. Co., the district court found that the lawyer had contributed to the absence of a witness. ${ }^{61}$ For this and other violations, the district court imposed a sanction of $\$ 162,011$ on the lawyer and his client, holding the two jointly and severally liable. ${ }^{62}$ The district court also issued a Rule 11 sanction of more than $\$ 4,800$ against the lawyer individually for rearguing an issue already decided by a judge previously assigned to the case. $^{63}$

On appeal, after a settlement, the Seventh Circuit compared the sanctions to tort remedies "which [ ] regulate behavior by compensating injured parties." ${ }^{.64}$ As parties are allowed to bargain away tort compensation, the court reasoned that parties could settle sanctions as well, despite their partially regulatory nature. The court found the award merely compensatory, and the appeal therefore moot. ${ }^{65}$ The court noted that a district court may avoid this result and punish a party by forcing payment of fines to the court or by using nonmonetary sanctions. ${ }^{66}$ While the court dismissed the lawyer's allegations of harm to his reputation as a "speculative contingency," it suggested "mandamus might be an appropriate remedy" if the lawyer could ever show "concrete harm to his reputation from the bare existence of [the] unpublished opinions." ${ }^{\text {"67 }}$ The court next vacated the sanction, finding it within the rule of Munsingwear because the attorney had lost his ability to appeal through no fault of his own: "Al-

B1 972 F2d 817, 818 (7th Cir 1992).

62 Id. The court issued sanctions for statutory civil contempt under 18 USC § 401, and for violations of FRCP 11, 26, and 37. Id.

63 Id. Ultimately, the court allowed the client to moot its lawyer's appeal by paying this sanction, for which the lawyer was solely liable.

bs Id at 819 .

65 Id.

68 Id.

${ }^{67}$ Id at 820. 
though we must wonder why [the client] chose to be so generous, there is no suggestion in the record that [the lawyer] had any hand in crafting the settlement."

The Eleventh Circuit, in Kleiner $v$ First Nat'l Bank of Atlan$t a$, used vacatur to avoid squarely facing the mootness issue. ${ }^{69}$ The district court found that the sanctioned lawyer, in an attempt to head off a class action, had.taken part in an illegal scheme to induce members to opt out of the class. ${ }^{70}$ The court imposed several sanctions: disqualification of the attorney, fines payable to the court, and fees and costs incident to the class notice and disciplinary proceedings payable to the opposing party. ${ }^{71}$ Following settlement of the case, the attorney sought to appeal the sanctions payable to the opposing party. ${ }^{72}$ The court cited Munsingwear and ruled, with scant discussion, that the sanctions should be "vacate[d] as moot," perhaps because the parties apparently agreed that "settlement ha[d] mooted [the] issues."73

\section{Reviewing the sanction.}

Finally, the Eighth Circuit found that a settled sanction presented an appealable case. In Perkins $v$ General Motors Corp., the district court imposed multiple sanctions upon the lawyer for engaging in "abusive litigation tactics," intentional harassment, and "affirmative misrepresentation." The district court assigned no monetary figure to the sanctions since, under a settlement, the opposing party had agreed not to collect. Nevertheless, the Eighth Circuit allowed an appeal. ${ }^{75}$

In effect, the court reasoned that payment by a party does not eliminate the impact of a sanction. The court focused on its own, as opposed to the lawyer's, interests, stating that "[a]ppellants are entitled to bargain with adversaries to drop a motion for sanctions, but they cannot unilaterally bargain away the

68 Id at $819 \mathrm{n} 1$.

697 F2d 1193 (11th Cir 1985).

70 Id at 1199.

71 Id. The fines payable to the court totalled $\$ 50,000$. The costs incurred by the other party totalled over $\$ 58,000$.

72 The court allowed appeal of the fines payable to the court because these were "imposed pursuant to the inherent powers of the district court and [were] not subject to revocation by the parties." Id at 1200 . The court also permitted appeal of the disqualification of counsel from the underlying case. Id at $1200 \mathrm{n} 14$.

73 Id at 1199.

74 129 FRD 655, 660-63 (W D Mo 1990), aff'd, 965 F2d 597 (8th Cir 1992).

75 Perkins v General Motors Corp., 965 F2d 597, 599-600 (8th Cir 1992). 
court's discretion in imposing sanctions and the public's interest in ensuring compliance with the rules of procedure." ${ }^{.76}$ The court indicated that sanctions are intended to have a significant residual impact upon the lawyer since "[t]he purpose of sanctions goes beyond reimbursing parties for expenses incurred .... Rather, sanctions are 'designed to punish a party who has already violated the court's rules." "'77 Since the court granted an appeal, the vacatur issue became irrelevant. ${ }^{78}$

\section{ANALYSIS: DECISIONS AND DOCTRINE}

In settled sanction cases, the circuit courts have reached conclusions without much supporting analysis. This Section will examine the bases for the courts' decisions, including the courts' treatment of the sanctions as punitive or compensatory. However, the analysis must move beyond this conclusory distinction. This Section calls upon basic mootness and vacatur principles to provide a firmer doctrinal basis for resolving settled sanction cases.

A. The Circuit Courts' Approaches: Compensatory and Punitive Sanctions

The courts' varying treatments of settled sanction appeals is explained to some extent by the courts' differing characterizations of the sanctions. The cases denying appeal, most explicitly Clark, viewed sanctions payable to the opponent as compensatory. For example, Clark compared these sanctions to tort remedies "which regulate [ ] by compensating" in contrast to sanctions payable to the court which are designed only to punish. ${ }^{79}$ On this view, the agreement to pay the fine eliminates the essential compensatory element of the sanction. Thus, either no interest remains to support a case, or the interest is too small to merit adjudication.

In contrast, Perkins, the case allowing appeal, viewed sanctions as primarily punitive. The court noted that sanctions go beyond reimbursement since they "are designed to punish." The stigma and other repercussions of a sanction remain after a fine has been paid.

78 Id at 600 .

7 Id at 599, quoting Willy $v$ Coastal Corp., 112 S Ct 1076, 1081 (1992).

78 The lawyer won only an appeal. The court reviewed the underlying record and summarily upheld the sanctions under an abuse-of-discretion standard. $965 \mathrm{~F} 2 \mathrm{~d}$ at 602 .

79 972 F2d at 819. See text accompanying notes $61-68$.

so 965 F2d at 599. See text accompanying notes 74-78. 
The position that sanctions are merely compensatory has significant weaknesses. First, by focusing on the irrevocable settlement of the sanction between the parties, this position denigrates the lawyer's role in incurring the sanction and confronting its effects. The courts allow the parties to determine a matter affecting the lawyer's interests without making the lawyer a represented party. ${ }^{81}$

Moreover, the recent amendment to Rule 11 makes clear that this frequently used sanctioning device is primarily intended to deter, not compensate: "A sanction imposed for violation of this rule shall be limited to what is sufficient to deter repetition of such conduct or comparable conduct by others similarly situated. ${ }^{\text {s2 }}$

Finally, the compensatory position ignores the Supreme Court's characterization of sanctions, even those paid to an opponent, as essentially punitive ${ }^{83}$ Certainly, deterrence and compensation are not mutually exclusive ends; ${ }^{84}$ however, the Court has pointed out that sanctions primarily punish and deter. ${ }^{85}$ Sanctions exist to ensure the "proper functioning of the legal system," not to satisfy "the burdened party's interest in recovering its expenses." ${ }^{\text {s6 }}$

The punitive characterization comports with the Court's characterization of sanctions; however, the correct characterization is not a proper end in itself. Characterizing the sanction as punitive helps emphasize the significant effects the sanction can have on a lawyer. But this fails to strike directly at the mootness problem.

82 The lawyer is unrepresented, not because he is uninvolved in the settlement talks, but because he must subordinate his own interests to those of his client. See note 9 and accompanying text.

${ }_{82}$ FRCP 11(c)(2), as amended April 22, 1993, and effective December 1, 1993. See also Advisory Committee Notes to the amended Rule 11 ("the purpose of Rule 11 sanctions is to deter rather than to compensate"). Although the amended Rule 11 reemphasizes deterrence, it also shifts all discovery sanctions to the more compensatory Rule 37 . See note 3 .

${ }^{83}$ Willy, $112 \mathrm{~S} \mathrm{Ct}$ at 1081 ("Rule 11 is designed to punish a party who has already violated the court's rules.").

84 See Brandt v Schal Ass'n, Inc., 960 F2d 640, 645-46 (7th Cir 1992) (finding deterrence and compensation compatible, but recognizing the primacy of deterrence).

B5 Willy, $112 \mathrm{~S} \mathrm{Ct}$ at 1081.

${ }^{86}$ Cooter \& Gell v Hartmarx Corp., 496 US 384, 390 (1990) (citation omitted). 


\section{B. A Fresh Approach: Applying Old Doctrines}

1. Settled sanctions and constitutional mootness.

Riverhead explicitly mooted an appeal on constitutional grounds. ${ }^{87}$ The constitutional mootness doctrine ensures adversarial presentation and prevents courts from intruding upon the other branches of government. ${ }^{88}$ A settled sanction does not raise these concerns, however, and the constitutional mootness doctrine should therefore present no barrier to settled sanction appeals.

Problems with adversarial presentation provide no basis for mooting a settled sanction. Settled sanction cases have acknowledged that an attorney may always appeal a sanction payable to the court. ${ }^{89}$ If the lack of an adversary cannot bar the appeal of a sanction payable to the court, then it should not bar an appeal when the sanction is payable to an opponent. Further, because misconduct often occurs before a district court, the record provides an excellent basis for review by the appellate court; the appellate court should not need much adversarial assistance to construct the full story. ${ }^{90}$

Nor does the settled sanction produce a reasonable fear of intrusion upon other branches. An attorney sanction is largely a matter of intrabranch administration. The federal courts have a strong interest in requiring that lawyers, as officers of the court, obey the rules of procedure. The Supreme Court made clear in Cooter \& Gell $v$ Hartmarx Corp. that the primary goal of sanctions is to ensure the efficient functioning of the courts. ${ }^{91}$ The Court has also consistently recognized the federal courts' inherent power to deal with sanctions. The Supreme Court has stated that inherent powers are "governed not by rule or statute but by the control necessarily vested in courts to manage their own affairs so as to achieve the orderly and expeditious disposition of cases." ${ }^{\text {"I }}$ In addition, Congress has affirmed the courts' control of attorney discipline. The Rules Enabling Act allows the Court to "prescribe general rules of practice and procedure and rules of evidence for cases in the United States district courts ... and

87893 F2d at 1112.

B8 United States Parole Comm'n v Geraghty, 445 US 388, 396 (1980).

${ }_{99}$ Kleiner, 751 F2d at 1200; Riverhead, 893 F2d at 1112; Clark, 972 F2d at 818.

so Wright, Miller, and Cooper, 13A Federal Practice and Procedure $\S 3533.10$ at 424 (cited in note 20 ).

$91 \quad 496$ US at 393.

${ }_{92}$ Chambers v NASCO, Inc., 501 US 32, 43 (1991) (citation omitted). 
courts of appeals." ${ }^{\text {"93 }}$ While courts cannot apply these rules to impermissibly expand their Article III authority, ${ }^{94}$ the congressional grant supports judicial power in the sanction area.

Finally, the settled sanction passes the oft-cited constitutional mootness requirements of a "personal stake" or "legally cognizable interest. ${ }^{966}$ As described above, the personal stake requirements do not measure the size of the interest a lawyer must possess; instead, they ensure that a lawyer has some personal interest that the court could potentially protect. ${ }^{97} \mathrm{~A}$ sanctioned lawyer has no "disembodied civic interest" or desire for an advisory opinion. ${ }^{98}$ In a settled sanction case, the lawyer demands review of a specific sanction that affects a legal interest; indeed, in In re Smith, the court ranked reputation with money and liberty as a tangible legal interest..$^{99}$ A settled sanction falls well within a federal court's constitutional jurisdiction. ${ }^{100}$

\section{Settled sanctions and prudential mootness.}

Other courts have apparently relied on prudential mootness to resolve settled sanction cases. ${ }^{101}$ Kleiner mooted an appeal of a settled sanction without direct reference to the Constitution, ${ }^{102}$ while Clark made only an oblique reference to the Constitution. ${ }^{103}$ If the Kleiner and Clark courts employed prudential mootness, they pushed far beyond the limits established elsewhere for the doctrine.

Courts have generally restricted their use of prudential mootness to cases where they could not grant "any effectual relief," 104 or relief was too "attenuated and remote" to pursue.

93 28 USC § 2072 (1988 \& Supp 1990).

94 See Willy, $112 \mathrm{~S} \mathrm{Ct}$ at 1079.

95 See Geraghty, 445 US at 396.

${ }^{96}$ See Powell, 395 US at 496.

97 See text accompanying notes 27-28.

${ }^{98}$ Compare Los Angeles County v Davis, 440 US 625, 633 (1979).

99 964 F2d 636, 638 (7th Cir 1992).

100 Given this conclusion, this Comment does not consider whether the settled sanction would fall within a constitutional mootness "exception" for issues that could subject a litigant to civil liability or criminal conviction. For a discussion of constitutional mootness "exceptions," see Kipp D. Snider, The Vacatur Remedy for Cases Becoming Moot Upon Appeal: In Search of a Workable Solution for the Federal Courts, 60 Geo Wash L Rev 1642, 1643-44 (1992).

101 See text accompanying notes 29-34.

102 Kleiner, 751 F2d at 1199-1201.

${ }^{103}$ Clark, 972 F2d at 819-20.

${ }_{104}$ Adams $v$ Resolution Trust Corp., 927 F2d 348, 354 (8th Cir 1991).

105 United States $v$ Street, 933 F2d 1010 (6th Cir 1991) (unpublished disposition re- 
In settled sanction cases, a court has the power to grant a lawyer precisely what he asks for-a chance to defend his reputation on appeal or a clean slate through vacatur.

Further, a settled sanction does not present a case where the relief would make so little difference that a court should refuse an appeal simply to preserve its own resources. ${ }^{106}$ The federal courts have consistently recognized the serious collateral effects of a judicial proclamation of intentional or egregious misconduct. ${ }^{107}$ In United States $v$ Schrimsher, the court allowed an appeal from a conviction for criminal contempt after examining the possible harm to an attorney's law practice and opportunities on the bench. ${ }^{108}$ In Bolte $v$ Home Insurance Co., the court compared the stigma of being accused by a federal judge of reprehensible conduct to defamation. ${ }^{109}$ In Kirkland $v$ Nat'l Mortgage Network, Inc. ${ }^{110}$ the court declined to moot an attorney's appeal of the revocation of his pro hac vice status ${ }^{111}$ because the revocation on "grounds of dishonesty and bad faith could well hang over his name and career for years to come." The settled sanction cases involve alleged misbehavior of similar gravity. ${ }^{112}$

Indeed, each settled sanction decision in some manner recognizes the importance of the sanctions to the lawyer. The Perkins court granted an appeal because it focused on the seriousness of

ported in full at 1991 US App LEXIS 11463). See also First Indiana Federal Savings Bank v FDIC, 964 F2d 503, 507 (5th Cir 1992).

${ }^{108}$ Compare Air Line Pilots Ass'n Intl., 897 F2d at 1397.

${ }^{107}$ Cases involving a lawyer's right to an interlocutory appeal, which fall outside the scope of this Comment, take the impact of sanctions upon a lawyer quite seriously. When a lawyer has been sanctioned, the cases either provide for an interlocutory appeal (albeit because the lawyer may be precluded, as a nonparty, from review after a final judgment or settlement) or suggest that an appeal will be available after final judgment. See Sanko Steamship Co., Ltd. v Galin, 835 F2d 51 (2d Cir 1987) (interlocutory appeal granted); Frazier v Cast, 771 F2d 259 (7th Cir 1985) (same); Crookham v Crookham, 914 F2d 1027 (8th Cir 1990) (same); DeSisto College Inc. v Line, 888 F2d 755 (11th Cir 1989) (same). See also In re Licht and Semonoff, 796 F2d 564 (1st Cir 1986) (sanction reviewable after final judgment); Eastern Maico Distributors, Inc. v Maico-Fahrzeugfabrik G.m.b.H., 658 F2d 944 (3d Cir 1981) (same); G.J.B. \& Assoc., Inc. v Singleton, 913 F2d 824 (10th Cir 1990) (same).

${ }^{108} 493$ F2d 842, 844 (5th $\mathrm{Cir} 1974$ ). Under the collateral consequences doctrine, a "criminal case is moot only if it is shown that there is no possibility that any collateral legal consequences will be imposed on the basis of the challenged conviction." Sibron $v$ New York, 392 US 40, 57 (1968).

${ }_{109} 744$ F2d 572, 573 (7th Cir 1984).

110884 F2d 1367, 1370 (11th Cir 1989).

111 Pro hac vice status allows a lawyer "to practice in a local jurisdiction for a particular case only." Black's Law Dictionary 1212 (West, 6th ed 1990).

${ }^{112}$ The facts of the four settled sanction cases are described in the text accompanying notes 52-78. 
the punitive sanctions. The Clark court avoided the conceded ramifications of mooting the case by vacating the judgment: "If the appeal is moot, [the lawyer] has a serious complaint: the district court found he had engaged in grossly unprofessional conduct ...." Even the Riverhead court, which mooted the claim and refused to vacate the sanction, backhandedly recognized the weight of the sanction by emphasizing the importance of keeping the decision "on the books."114 Finally, although the Kleiner court refused to hear an appeal of sanctions that the parties agreed were moot, it did hear a related appeal of the lawyer's disqualification: "The disciplinary action and consequent disqualification may expose counsel to further sanctions by the bar and portends adverse effects upon counsel's careers and public image. The effects of disqualification will linger long after the closing of the case."115

Since the courts have the power to grant relief and concede that a sanctioned lawyer has significant interests, the courts should not employ prudential mootness in settled sanction cases.

\section{Settled sanctions and vacatur.}

If, notwithstanding the above analysis, a court were to declare a settled sanction case moot, it would proceed to consider whether to vacate the sanction. In Clark and Kleiner, for example, the courts protected the sanctioned lawyers by vacating the judgments imposing sanctions. Vacatur assuages a lawyer's concern about repercussions from a sanction. Further, if the lawyer anticipates that he will be granted either an appeal or vacatur, he avoids a potential conflict with his client over settlement. ${ }^{116}$

On the other hand, vacatur eliminates the penalty for actions that the district court viewed as serious violations. By mooting and vacating, an appellate court preserves its resources at the expense of rules that were designed to streamline the litigation process. Sanctions provide both general and specific deterrence; ${ }^{117}$ a decision to vacate affects the entire judicial system, not just an individual court and lawyer.

113 Clark, 972 F2d at 819.

114 In examining the vacatur issue, the court balanced the problem caused by refusing to review the sanction against the impact of a review on finality and the value of keeping the decision "on the books." Riverhead, 893 F2d at 1113.

115 Kleiner, 751 F2d at $1200 \mathrm{n} 14$.

${ }_{116}$ See Cheng $v$ GAF Corp., 713 F2d 886, 889 (2d Cir 1983).

117 Cooter \& Gell, 496 US at 404. 
Normally, determining whether vacatur is appropriate for a settled case simply entails an investigation into whether the party requesting the appeal voluntarily mooted the case. If the party did not, Munsingwear dictates that the court must vacate. If the party did in fact voluntarily moot the case, courts disagree over the propriety of vacatur. ${ }^{118}$

This inquiry is ill suited to settled sanction cases. First, a court usually has no reason to presume that an attorney violated his duty to a client by inducing a settlement to attain vacatur of his own sanctions. ${ }^{119}$ Even if a court suspected that an attorney's interests played a role in the settlement, the court would find it difficult to confirm its suspicion. The problem of penetrating the attorney-client relationship prevents effective inquiry. ${ }^{120}$ Indeed, if the court had the capacity to penetrate the relationship, it probably would not have sanctioned the lawyer and client jointly in the first place. ${ }^{121}$ So, if an attorney did not voluntarily moot the case, or, at a minimum, if the court cannot uncover the attorney's influence, the rule of Munsingwear should compel vacatur.

Finally, even if a court could show that a lawyer had a role in mooting his sanction, the court should still vacate. ${ }^{122}$ The circuits disagree over whether courts should routinely vacate a judgment after voluntary mootness. The circuits that deny vacatur typically seek to preserve three things: precedent, preclusive value, and a public record. ${ }^{123}$ Denying vacatur in settled sanction cases does little to promote these ends.

First, a district court opinion binds no other court. If an appellate court wants to protect the small persuasive value of the

11 For a description of this debate, see the text accompanying notes 35-51.

119 See, for example, Clark, 972 F2d at 819 n 1 (finding "no suggestion in the record that [the attorney] had any hand in crafting the settlement"). Of course, the attorney may find it hard not to factor his personal preferences into a decision to advise the client to settle.

120 Apparently this did not dissuade the Clark court from looking. Id at 820 .

${ }_{121}$ See Eastway Construction Corp. $v$ City of New York, 637 F Supp 558, 569 (E D NY 1986), modified, $821 \mathrm{~F} 2 \mathrm{~d} 121$ (2d Cir 1987) (adjusting size and allocation of sanctions).

${ }^{122}$ It is not the role of this Comment to resolve the general dispute among the circuits regarding vacatur following voluntary mootness. However, the settled sanction does present a case which perhaps even a strong "public law" advocate might agree to vacate. For a discussion of values surrounding the decision to vacate after settlement in the context of settlement conditioned upon vacatur, see Note, 58 Fordham L Rev at 233 (cited in note 48); Note, Avoiding Issue Preclusion by Settlement Conditioned upon the Vacatur of Entered Judgments, 96 Yale L J 860 (1987).

${ }^{123}$ Memorial Hospital, 862 F2d at 1302. 
unreviewable sanction decision of the district court, ${ }^{124}$ the court can simply provide its reason for vacating. This will assure those who later read the decision that the vacatur did not call the merits of the district court's reasoning into doubt. ${ }^{125}$ Second, a sanction decision probably has no practical preclusive value. If preclusion does threaten the lawyer, however, the court should not moot the case in the first place since the lawyer would have a recognizable interest at stake. ${ }^{126}$ Third, a court should not refuse to vacate merely to preserve a record against a "party who thumbs his nose at the orderly process of the court."127 The court has little legitimate interest in preserving a public record of "wrongdoing"-especially after refusing review of the judgment. ${ }^{128}$ Either the lawyer's interest is important enough to support an appeal, or it is unimportant enough to vacate. ${ }^{129}$

A lawyer's appeal of a settled sanction is not moot. Moreover, even if a court finds the appeal moot, Munsingwear calls for a court to vacate the judgment imposing the sanction if the attorney played no role in mooting the appeal. In the unlikely event that a court finds that the lawyer had a significant role in rendering the appeal moot-as no court has yet done-Munsingwear may not require vacatur, but the settled sanction presents an unusually strong case for vacatur.

\section{Beneath the Doctrine: PRESent INTERESTS, INCENTIVES, AND AGENCY}

The previous Sections examined the doctrinal bases for allowing an appeal or vacatur. This Section looks beneath the doctrine and considers whether it makes sense to provide relief to the sanctioned lawyer. First, this Section examines an economic model that explains Article III justiciability doctrines like mootness. Next, the Section raises arguments to rebut the con-

124 See id (vacatur "clouds and diminishes the significance of the holding").

125 See Fisch, 76 Cornell L Rev at $630 \mathrm{n} 221$ (cited in note 35).

${ }_{126}$ Edgar $v$ MITE Corp., 457 US 624, 630 (1982).

127 Memorial Hospital, 862 F2d at 1302.

${ }_{123}$ Resort to the original voluntary mootness argument (that the lawyer gave away interests in preclusion and the record by participating in the settlement) is hobbled by the fact that the lawyer lacked leverage in the settlement. He could not, for example, pressure the court by conditioning settlement on vacatur; his duty to the client prevents him from fully protecting his interests.

129 This argument holds for either a single violation or for the cumulative effect of a series of violations. If the court keeps a running tally, the importance of review for each sanction increases. Further, vacatur of the judgment does not limit the judicial system's ability to keep statistics on sanctions; the underlying information does not disappear. 
tention that it is less costly to ignore a sanctioned lawyer's concerns than to address them. This Section then concludes with an application of these arguments to the three ways in which courts may resolve a settled sanction appeal.

\section{A. Constitutional Mootness, Premature Decisions, and Risk}

The first mootness inquiry corresponds to what the last Section labelled "constitutional mootness." Professor Landes and Judge Posner have presented a model to explain Article III's case or controversy requirement and its exceptions. ${ }^{130}$ At the simplest level, the decision whether to provide a forum when a dispute is not "live" balances the costs of resolving a dispute that may not arise (and the errors that go along with an early decision $)^{131}$ against the benefit of eliminating uncertainty. ${ }^{132}$

A party could rationally seek a court decision in a case where she no longer had a live interest if a decision would permit her to repeat the conduct that forced the initial litigation (or provide certainty that she cannot get permission). As an example, Landes and Posner point to an importer whose fruit spoiled while he waited for an appeal. Although he cannot recover the lost fruit, the importer might pursue an appeal that would allow him to import the same type of fruit in the future. ${ }^{133}$

A settled sanction is not moot within this model. First, unlike the importer, the sanctioned lawyer has not given up on her original case. Instead, she seeks to stop the damage she suffers under the original judgment. Given the difficulty of an appeal under the abuse-of-discretion standard and the fact that an attorney must pay for her own appeal of a settled sanction, a rational lawyer will appeal only when she has a significant, immediate interest. Since the attorney has a live case, she avoids the need for the model's balancing test-no costs of premature decision exist.

${ }^{130}$ William M. Landes and Richard A. Posner, The Economics of Anticipatory Adjudication, paper delivered at The University of Chicago Law School Workshop in Law and Economics (April 27, 1993) (on file with U Chi L Rev).

${ }^{131}$ Unlike other anticipatory-adjudication problems, the moot case does not invite error by forcing the court to decide a case on hypothetical facts. The first run-through provides the court with the facts necessary to decide the case. Id at 40 . It is possible, however, that the settled sanction appeal presents a greater chance for error than the typical moot case since the lawyer usually does not have an opponent.

${ }_{132}$ Id at $3-4$.

230 Id at $40-41$. 
Of course, in some of the most meritorious appeals, the attorney stands to gain collateral future benefits; for example, a lawyer sanctioned for an allegedly frivolous complaint may, through successful appeal, reduce the risk of trying the theory again in another case. As with the importer, this risk reduction weighs in favor of granting an appeal.

\section{B. Prudential Mootness, Agency Costs, and Incentives}

Courts also moot cases when they see so little potential benefit to the plaintiff that the court should not expend its resources. This Section provides additional reasons, beyond the serious consequences that a lawyer faces from a sanction, why a court should spend its resources on an appeal of a settled sanction. If the court does not, the lawyer and client face substantial agency costs both from an ex ante and ex post sanction perspective. The judicial system ultimately shares these costs. Further, failure to allow an appeal distorts incentives designed to prevent sanctionable conduct.

Mootness and vacatur rules have a significant impact on the attorney-client relationship because it is difficult for the attorney and client to contract around the rules governing that relationship. For example, courts will not enforce a bargain that gives a lawyer veto power over her client's settlement. ${ }^{134}$ The courts may also refuse to enforce a client's agreement to indemnify its lawyer for sanctions incurred. ${ }^{135}$

The settled sanction presents a complex agency problem because it challenges the assumption that professional ethical rules, reputation, and contractual restrictions can force perfect alignment between lawyer and client. ${ }^{136}$ When an attorney and client face a joint sanction, they both own an interest in the suit. Professor Miller has described this claim-sharing arrangement as a dual agency in which the client and lawyer act for one another. ${ }^{137}$ This dual agency causes problems because the two have divergent underlying interests. The legal system at-

134 Zack v NCR Corp., 738 F Supp 933, 936 (E D Pa 1990).

${ }^{135}$ Eastway Construction Corp. $v$ City of New York, 637 F Supp 558, 570 (E D NY 1986), modified, 821 F2d 121 (2d Cir 1987). See also Wold v Minerals Engineering Co., 575 F Supp 166, 168 (D Colo 1983) (barring a sanctioned law firm from receiving any indemnity from its client).

${ }^{235}$ See generally David B. Wilkins, Who Should Regulate Lawyers?, 105 Harv L Rev 799, 805-09 (1992) (suggesting four methods of controlling lawyers: disciplinary controls, liability controls, institutional controls, and legislative controls).

${ }^{237}$ Miller, $16 \mathrm{~J}$ Legal Stud at 190 (cited in note 6). 
tempts-unsuccessfully-to resolve the problem by giving full settlement power to the plaintiff. ${ }^{138}$ In practice, the prohibitive cost of perfectly monitoring or bonding the lawyer forces "a flexible sharing arrangement" covering control over settlement. ${ }^{139}$ Even the courts have recognized that once an attorney acquires an interest in a suit, that attorney's interests will help shape the settlement. ${ }^{140}$

The settled sanction raises the potential for severely misaligned interests between the dual agents. Even assuming that client and lawyer place the same value on the pecuniary aspect of a sanction, a lawyer has a stronger interest in avoiding a sanction. A lawyer, as a repeat player in the legal system, has more at stake in business reputation, professional credentials, and her relationship with members of the bar. ${ }^{141}$

A solution that minimizes this divergence of interests helps minimize agency costs, which include "the costs of structuring, monitoring, and bonding a set of contracts among agents with conflicting interests, plus the residual loss incurred because the cost of full enforcement of contracts exceeds the benefits." $142 \mathrm{Be}$ cause the attorney-client agency already entails unusually high costs, the relationship deserves special protection from factors that may strain it. As noted above, courts limit the parties' ability to structure a contract. ${ }^{143}$ Clients also frequently lack the sophistication required to effectively monitor lawyers. ${ }^{144}$ Finally, normal liability controls do not work well against lawyers: malpractice claims are hard to win given the standard of proof and judicial deference to lawyers; lawyers have leverage over their clients because they hold confidential information that they may expose in defense; and clients who sue lawyers risk difficulty in locating legal services in the future. ${ }^{145}$

${ }^{138}$ See id.

139 Id at 213 .

${ }^{140}$ See, for example, Cheng $v$ GAF Corp., 713 F2d 886, 889-90 (2d Cir 1983) ("If the fee issue is linked to settlement negotiations, appellant's lawyer may be placed in an ethical dilemma; his view of any settlement proposal would almost certainly be colored by its handling of the attorneys' fee issue.").

${ }^{141}$ See Bundy and Elhauge, 79 Cal L Rev at 354 (cited in note 4).

${ }^{112}$ Eugene F. Fama and Michael C. Jensen, Agency Problems and Residual Claims, 26 J L \& Econ 327, 327 (1983).

${ }^{163}$ See text accompanying notes 134-35.

${ }^{34}$ But see Wilkins, 105 Harv $L$ Rev at 816-17, 828-29 (cited in note 136) (noting that repeat players like corporations violate this assumption).

145 Id at 831-32. 
The judicial system also has a significant stake in assuring alignment between lawyer and client interests. Clearly, the judicial system suffers when lawyers, as officers of the court, prevent clients from achieving their goals. More concretely, the judicial system incurs substantial costs in creating, monitoring, and enforcing regulations designed to ensure that lawyers serve clients. The bar associations' disciplinary systems bear substantial costs in policing lawyers. ${ }^{146}$ Federal courts and agencies also monitor the lawyers practicing before them and hear cases brought against lawyers. ${ }^{147}$

Of course, any assessment of the value of proper incentives must be weighed against the costs of providing the incentives through appeal or vacatur. ${ }^{148}$ Unfortunately, this cost is difficult to measure. Clearly, an appeal creates administrative costs; however, as a rule, the legal system provides appeals, indicating that having errors corrected, litigants satisfied, and precedents established is presumed to outweigh administrative costs. Similarly, the cost of routinely granting or denying vacatur remains unclear: courts and commentators differ sharply over this issue. ${ }^{149}$

\section{Evaluating the Alternative Approaches}

Since the cost of providing incentives through appeal or vacatur remains unclear, it seems wise to shape the incentives to minimize other, more obvious, costs. This Section examines the incentives provided by the three alternative ways in which a court may resolve a settled sanction appeal.

\section{Refusing an appeal and vacating the judgment.}

The first option is to deny an appeal, but to vacate as a matter of course. This option, however, fails to satisfy the goals of preventing sanctionable conduct and aligning attorney and client interests. If a lawyer anticipates vacatur upon settlement, the threat of a sanction provides too little deterrence. The lawyer can

${ }^{146}$ Id at 829 n 118, citing Commission on Evaluation of Disciplinary Enforcement, American Bar Association, Report to the House of Delegates 49 n 15 (1991), for the proposition that the bar spent $\$ 74.4$ million on discipline in 1988 .

${ }_{147}$ Wilkins, 105 Harv L Rev at 807-08 (cited in note 136).

${ }^{148}$ Jonathan R. Macey and Geoffrey P. Miller, The Plaintiffs' Attorney's Role in Class Action and Derivative Litigation: Economic Analysis and Recommendations for Reform, 58 U Chi L Rev 1, 19 (1991). Compare the attempt by Macey and Miller to capture the expenditure on control devices with the calculation of a residual loss by Fama and Jensen (see text accompanying note 142).

${ }^{149}$ See text accompanying notes 43-50. 
simply discount the personal costs of the sanction by the overwhelming probability that the case will settle. ${ }^{150}$

Further, this alternative fails to align the lawyer's interests with her client's. Again, the analysis begins with the assumption that a lawyer has a stronger interest in avoiding the nonfinancial consequences of a sanction than does her client. Once the court imposes a sanction, a lawyer will have an incentive to exert pressure for a settlement. Although the lawyer could potentially contest the sanction if the case continued through an appeal, the lawyer would far prefer vacatur to an appeal tested under an abuse-of-discretion standard. While the client theoretically retains the power to veto a settlement, it often lacks the capacity to discern the extent to which the sanction biases its lawyer in favor of settlement.

This conflict cannot easily be resolved ex ante, because the client cannot bind itself to change its settlement decision or internalize the lawyer's costs.

2. Refusing an appeal and refusing vacatur.

Denying an appeal and refusing to vacate also fails to achieve both goals. First, this option may overdeter lawyers. Refusing appeals presumptively increases the number of erroneous final sanction judgments. Adding this error to the refusal to vacate creates a cliff's edge-because of the risk of an irreversible sanction, a lawyer may avoid some types of cases or practices that involve aggressive but putatively nonsanctionable conduct. Thus, denying all recourse to the lawyer may deny adequate counsel to some groups of litigants ${ }^{151}$ and free some "overzealous" trial judges to apply sanctions against disfavored groups. ${ }^{162}$

Problems also emerge after a court imposes sanctions: once a lawyer has been sanctioned, she may unduly pressure her client to continue litigation, for this offers her only hope of appealing the sanction. Again, ex ante, the client cannot bind itself to prevent these problems.

150 To the extent the lawyer controls settlement, she can ensure vacatur.

151 Solo practitioners and lawyers prosecuting employment discrimination and civil rights claims have been hit the hardest by Rule 11 . Denying all recourse exacerbates a problem that may currently "deprive certain citizens of meaningful access to the judicial system for their legitimate claims." Wilkins, 105 Harv L Rev at 869 (cited in note 136).

${ }^{152}$ Willging, The Rule 11 Sanctioning Process, 1988 WL 252121 (FJC) (cited in note 7). 
3. Allowing an appeal.

Allowing an appeal appears to satisfy both goals. First, an appeal supports the sanction regime. An appeal ensures that a lawyer gets at least an explanation of the sanction and other basic elements of due process that may otherwise be ignored when a district court imposes sanctions. ${ }^{153}$ On the other hand, the abuse-of-discretion standard keeps a trial court in control of the proceedings before it and limits appeals. Lawyers caught committing outrageous offenses will not waste their money on appeals under this standard. At the same time, civil rights lawyers and other sometimes-disfavored groups ${ }^{154}$ can benefit from dispassionate review.

Second, this option more closely aligns the interests of clients and lawyers. A lawyer knows that, whether the case settles or not, she will have the same opportunity to appeal her sanction. While a lawyer might prefer automatic vacatur upon settlement, lawyers have proven their willingness to pursue sanction appeals in the face of the abuse-of-discretion standard. This option thus minimizes the agency costs of the relationship between attorney and client. It has the further advantage of comporting with mootness doctrine, if not the majority of settled sanction cases.

\section{CONCLUSION}

Doctrine and policy agree: a lawyer with a settled sanction should have an appeal. Article III of the Constitution does not deny a federal court jurisdiction over a settled sanction case. The review of a sanction imposed by a court and designed to ensure the efficient functioning of the judicial system falls well within the powers allocated to the judicial branch.

Nor should a court deny relief simply to preserve its own resources. Courts properly employ prudential mootness only when the potential relief is too "attenuated and remote" to pursue. Even the courts in settled sanctions cases do not deny their power to provide significant relief. Denying review, whether or not the court vacates the decision to impose sanctions, fails to properly support the sanction regime. It also creates unnecessar-

153 See Sanko Steamship Co., Ltd. v Galin, 835 F2d 51, 52 (2d Cir 1987) (describing "due process requirements inherent in Rule 11 "). Rule 11 now requires the court to "describe the conduct determined to constitute a violation of this rule and explain the basis for the sanction imposed." FRCP 11(c)(2)(B)(3).

154 See note 151. 
ily high agency costs in the lawyer's relationship with her client. The judicial system ultimately bears many of the costs arising from this conflict. The federal courts can, and should, provide an appeal for lawyers facing settled sanctions. 


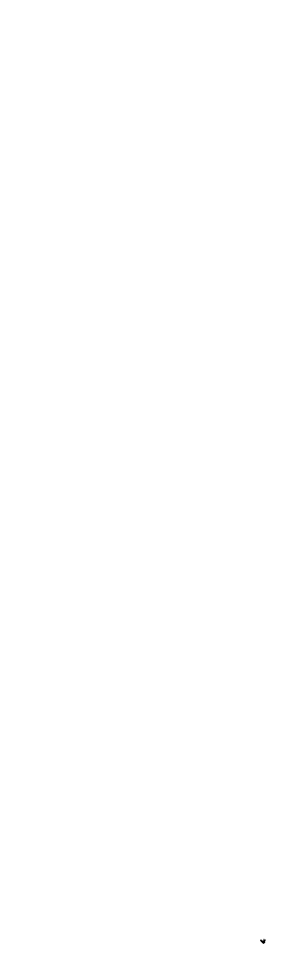

.

.

.

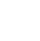

